\title{
KEYNES AND THE INTERPRETATION OF PROBABILITY VERSUS THE USE OF PROBABILITY THEORY IN OPTION PRICING
}

\author{
János Százi
}

\begin{abstract}
This essay reflects on the Bélyácz-Daubner paper (2020) published in the previous issue of this journal, which examined whether Keynes thoughts continue to have an effect today on how the concept of probability should be interpreted in business and economics. Complementing the cited paper, this essay draws attention to the fact that, in addition to the customary frequentist interpretation and the uncertainty stemming from limited knowledge, in modern finance the conditions that set out the criteria for consistent pricing include an interpretation that is not associated with past statistical frequencies or with the uncertain expectations of investors, but simply uses the tools of probability theory (Martingale pricing) to express the requirement for the consistent weighting of possible outcomes. Remarkably, weights that differ considerably from each other may be chosen for the purpose of correct relative pricing.
\end{abstract}

JEL codes: D84, D85

Keywords: option pricing, uncertainty, probability, predictability, Keynes, Arrow, Debreu, consistent pricing

Today, in the age of "big data", it is not only in the business sector that a growing number of people are increasingly convinced that we have collected almost all important data on the world thanks to every larger and faster computers and the omnipresent surveillance cameras; in higher education too, the analysis of a vast mass of data is intended to have a "future-shaping" role. There is no doubt that these tools are opening new horizons in many fields. There will be a need for legions of highly trained, specialist statisticians.

But has millisecond stock and currency trading enabled us to know significantly more about stock prices ten years into the future? Is it even possible to forecast

1 János Száz, Professor, Corvinus University Budapest. Email:janos.szaz@uni-corvinus.hu. 
prices in the long term? Keynes's theoretical answer to the long-term predictability of prices was an emphatic no. Granted, that was a long time before the emergence of big data, but it is hard to believe that more frequent intraday trading could better explain the long-term trend in market prices. ${ }^{2}$ Taking these two issues are our starting point, this brief essay reflects on two papers, one written jointly by Iván Bélyácz and Katalin Daubner (BD) $3{ }^{3}$ and other by Katalin Daubner (DK) ${ }^{4}$.

Let us reframe the two questions asked above. Can a bank know whether the loan it has provided will be repaid? This is undeniably an important question. Does the uncertainty lie in the nature of things, or does it stem from the limitations of our own knowledge? The BD study takes another run at these questions, similarly to Iván Bélyácz's 2011 paper (B11)5.

At the time, the (B11) paper sparked a debate in the pages of this journal's predecessor. ${ }^{6}$ A common feature of these papers is that they set out to answer the theoretical question of how the concept of probability should be interpreted in business and in economics, and more specifically in the financial markets.

Why is it worth asking this question again almost a decade later? What can the reader gain from this in today's bustling world? To answer the latter question first, perhaps because in higher education - not just at college level, but also at specialist economics universities - there is mostly only time for presenting answers, calculation methods and certain outputs of statistical software.

Sometimes, however, we need to stop and ask the question of what that number 55 really is, if it happens to be flashing on the screen at the time. And there are plenty of numbers flashing on the screens of bankers and brokers.

2 At the same time, it is worth mentioning that Keynes was not just an outstanding theoretical economist, but also multiplied the wealth of King's College, not to mention his own, with his regular morning telephone trades. He had a very good idea, therefore, of what goes through the minds of the investors whose trades directly determine the price trends. Economic factors do not affect prices directly or through equations, but only through the decisions of the market actors.

3 Bélyácz, Iván - Daubner, Katalin (2020): Logical Probability, Uncertainty, Investment Decisions. Did Keynes's logical theory of probability have impact on economic thinking? Economy and Finance $7(1), 2-46$.

4 Daubner, Katalin (2019): A valószínűség fogalmának többarcúsága [The Many Faces of Probability]. Tudományos Mozaik Vol.17. Budapest: Tomori Pál Főiskola, 83-98.

5 BÉLYÁCZ, Iván (2011): Kockázat, bizonytalanság, valószínűség [Risk, Uncertainty, Probability]. Hitelintézeti Szemle 10(4), 289-313.

6 Medvegyev, Péter (2011): Néhány megjegyzés a kockázat, bizonytalanság, valószínűség kérdéséhez [A Few Comments on the Question of Risk, Uncertainty and Probability]. Hitelintézeti Szemle 10(4), 314-324.; SzÁz, JÁnos (2011): Valószínűség, esély, relatív súlyok. Opciók és reálopciók [Probability, Chance, Relative Weights. Options and Real Options]. Hitelintézeti Szemle $10(4), 336-348$. 
Few future financial professionals sitting at their college desks are taught about the serious theoretical underpinnings of the most commonly used basic financial calculation, the present value calculation; specifically, the logic of intertemporal substitution. This chapter is now usually omitted.

Is it possible to give a meaningful answer to the question "what is the probability of repayment of a given loan"? Or can you only say that " $68 \%$ of loans of the given type are expected to be repaid"? Or perhaps just "it is more likely than not that the loans will be repaid"??

We should stress that the question is not whether the $68 \%$ is sufficiently accurate. ${ }^{8}$ The question is whether there is an objective measure for every event (which between $o$ and 1 is referred to as normal probability), in the way that objects have mass and volume. Or can we say no more than that Liverpool has better chances than Arsenal; repayment is more likely than default.

Are world events deterministic, and does the world as a whole function in accordance with certain differential equations ${ }^{9}$, or can the processes taking place inside the fundamental particles be described with probability variables? Einstein also railed against the latter supposition, saying "God does not play dice".

Katalin Daubner's informative study of what the great thinkers have said about the nature of probability and its applicability through the ages is highly thoughtprovoking: Is probability calculus only valid for card games, sequences of dice throws, or can it also be applied effectively in lending decisions, for example. The joint paper with Iván Bélyácz has a narrower focus: Have Keynes's thoughts on the substantiation of investor decisions (which are key factors in the functioning of the economy) left their mark on today's economics, where it is increasingly common to read about "rational expectations". Keynes certainly did not believe in such things. In his opinion, investors often just copy each other.

7 The latter is closer to the probability concept featuring in the subtitle of the (BD) paper.

8 Here it is worth invoking a joke that was popular in Hungary in the 1970, according to which a mummy is found in Egypt. They call the British scientists, who establish that the mummy's age is between 3200 and 3600 years. Then they call the Americans who, using more modern tools, determine that it is between 3300 and 3500 years old. Finally, thy call the Soviet scientists, who 3 days later announce that the mummy's precise age is 3412 years and 3 months. Everyone is astounded, but someone asks how they know. The classic answer: It confessed.

9 Laplace is often labelled as a champion of the deterministic world view, although if he were alive today he probably would not have used the sentences that are so oft-quoted today. At the time, the toolkit of differential equations had become a serious arsenal (due in no small measure to his work) and they solved problems that would have been no chance of solving before. This was the steam engine, the antibiotics, the atomic bomb of the age. It is no wonder that he was enthusiastic about the dawning of a new age. You just have to get it right... 
The (BD) paper is not light reading, while it draws our attention once again to certain fundamental issues. And these days it is not the philosophers ${ }^{10}$ who decide, but mostly the bankers, because the fate of so much money lies in their hands. What is it that they believe in when making their decisions based on the numbers? Hopefully not simply that this was what the computer came up with after processing millions of items of data. Is there a certain reference point, or a reference point that can be made sufficiently certain in decision-making situations that are full of uncertainty?

\section{Luca Pacioli}

There is no better place to start our intellectual adventure than the following problem. ${ }^{11}$ Two people are flipping a coin. If it comes up heads one wins, if tails the other. The pot of money put in by both players at the beginning is scooped by whoever wins 6 times. The game is interrupted at a score of 5:3. How can the amount be divided up fairly?

This problem features in Luca Pacioli's 1494 book "Summa de arithmetica, geometrica, proportioni et proportionalità". ${ }^{2}$ Luca Pacioli was a Franciscan monk, a contemporary and occasional colleague of Leonardo da Vinci. He is the creator of double-entry bookkeeping, making him the father of accounting.

The solution provided by Pacioli (5/8 and 3/8) was perfectly in line with his accounting approach based on past facts. However, the solution is wrong. Chevalier De Méré put the question 150 years later to Blaise Pascal, who solved the problem in the course of his correspondence with Pierre de Fermat $(7 / 8,1 / 8)$, incidentally defining 'present value' in the process. ${ }^{13}$

10 Incidentally, where have they got to these days? Not so long ago there was a module devoted to them at every university.

11 Given the important of this topic? I also described this problem with the same few lines of commentary in last year's issue of Economy and Finance compiled to mark the $30^{\text {th }}$ anniversary of the Hungarian Banking Association, see SzÁz, János (2019): Development and Risks. Financial intermediation and risk management in the era of Commodore 64 and today. Economy and Finance 6(1), 62-8o.

12 Summary of arithmetic, geometry, proportions and proportionality. Venice, 1494.

13 It is incredible that things can join together so neatly in relation to a simple, but beautiful old problem. The same is true of people, and the duality of the world that I believe plays a philosophical role in the perception of today's financial markets. Because the way we look at these markets cannot be separated from what we actually see there.

From this standpoint, teaching probability theory is at least as important as preparing students for the mechanical examination of masses of data. Of course, the two do not have to be mutually exclusive. 
Pacioli took past facts into account. The correct solution found by Pascal was based on what kind of winnings the two parties could secure, given a certain score, in the event of a continuation. ${ }^{14}$ This is precisely where we find today's deepening and widening chasm between risk analysts who investigate future possibilities, and accounting and law that focus on past facts. The emergence in accounting of the concept of market value, which is somewhat removed from the classic approach, may have been a response to this pressure. Probability theory concepts are also increasingly prevalent in laws. ${ }^{15}$

What can we hold on to, what can we trust more? The apparent certainty of the past, or the uncertain future? It is certainly important to also look to the past, as the iconic Hungarian rock band Illés sang in the late 196os: "Maybe things could have been different, maybe, but that's the way it turned out ..."

\section{The Benthamite Calculation}

According to the (BD) paper, "Keynes did not believe that entrepreneurs make a list of all the possible future outcomes, assign a probability to every item on the list, and then calculate the expected value. Entrepreneurs cannot perform a Benthamite calculation (Bentham, 1787) of long-term values. Keynes stated that "our existing knowledge does not provide a sufficient basis for a calculated mathematical expectation" (Keynes, 1936:152)".

The existence or non-existence of that theoretical list (see Péter Juhász's essay on scenario analysis ${ }^{16}$ in this journal) is intertwined with the Nobel Prize-winning hot topic of the 1990s: the correct pricing of derivative products (options, swaps, etc.). Many people believe some exotic variants of these products to be toxic because they play a major part in the emergence and spread of financial crises, for which there are two reasons. Partly it is due to the very high leverage inherent in them, but mainly because the true nature of the risk that they carry remains

14 In our example, if it continued the game would end in a maximum of 3 rolls. The player at a disadvantage could only take the pot by winning all three, otherwise the opponent would emerge victorious. The chances of him or her winning 3 times is $1 / 2^{3}=1 / 8$, so the opponent has a $7 / 8$ chance of winning.

The original problem was phrased in more general terms. I did not want to take advantage of the reader's attention and patience for too long, hence the simplified example. For the precise details, search Google for "Problem of points".

15 Sadly, the standalone teaching of probability theory has also disappeared from higher education in Hungary in recent years.

16 JuHÁsz, PÉTER (2020): Risk analysis in corporate financial modelling. Economy and Finance 7(1), 47-56. 
completely hidden in more complex cases, not only from accounting analysis (below-the-line items), but also to financial analysts, who are viewed as specialists. And, worst of all: from both parties to the transaction as well as the supervisory authority regulating it.

\section{The AD Model and the Criterion of Consistent Pricing}

The contradictory principle of derivatives pricing is easiest to understand and navigate using the model devised by Nobel Laureates Arrow-Debreu (AD). In this one-period model, the financial products taken into consideration are listed in the rows, while the columns contain the values of these products depending on which possible state has occurred.

As an example, here is the Black-Scholes-Merton model (in which there is a risk-free, a risky and a derivative product, e.g.: deposit, share, option) in the AD model ${ }^{17}$ :

$$
p=\left[\begin{array}{c}
1 \\
S \\
g=?
\end{array}\right] V=\left[\begin{array}{cc}
B & B \\
S u & S d \\
g_{u} & g_{d}
\end{array}\right]
$$

In this case the price either goes up $(u)$ or down $(d)$, and $g$ is a derivative product if it goes up at the same time as the underlying product $(S)$.

In general cases, the $V$ matrix is $m \times n$, and we refer to the complete market or an incomplete market based on its ranking and order.

Setting aside the mathematical details, the main message of the AD model is that we can only talk about consistent (arbitrage-free) pricing if the states (columns) have equal weighting for every product, and the expected value of each product at maturity is discounted with the same discount rate..$^{18}$ This model has no statistics or stochastics at all, but there is a full listing of all possible versions.

The (BD) paper makes several references to Arrow, whose most frequently cited model, however, takes this full listing as the starting point. For the purposes of the option closing application, the linear algebraic outcome weighting is translated into the language of probability, so that from this point on the full arsenal of probability theory tools (expected value, standard deviation, conditional prob-

17 For more detail, see SzÁz János (2019): Kvantitatív pénzügyek [Quantitative Finances], Chapter 5.1. Budapest: Nemzetközi Bankárképző Központ, 143-151.

18 The basic principle is the same as in the corner shop: The contents of every shopping basket must be priced on the basis of the same product price list, with consistent pricing. 
ability) can be applied. We only translate one linear algebraic consistency criterion (replicability) into the language of probability theory. There are no statistics, sampling or factors relating to the decision-maker's limited knowledge. The internal logical relationship of a multifactor structure is rephrased in the language of probabilities.

If anything, this has the most in common with Keynes's concept of logical probability; and it contains no relative frequency whatsoever. What we would say about the probability of an option being exercised is referred to in the literature as the $P$ rate, and for example what comes out of the $A D$ model is customarily known as the $Q$ rate. The former is called the "objective" rate, and the latter the "martingale" rate. Based on the former, the average yield of an average US stock is $12 \%$ in the long term, and $4 \%$ based on the latter. This is a striking difference. The two approaches can happily exist side-by-side: We use the former for calculating yield and risk in portfolio theory; and the latter, for example, for the arbitrage-free pricing of an option. The $\mathrm{Q}$ weighting not only assigns other values for changes in the price of a stock, but - counter-intuitively and contrary to our a priori expectations - leads to a point where, if two stocks have the same volatility but one has recently shown an upward trend while the other fell in value, then if the outcomes are weighted (consistently) with the $\mathrm{Q}$ rate the value of the two options will be the same. ${ }^{19}$ That really is not what we would expect...

\section{Expected Yield}

The (BD) paper states: "The biggest problem when examining the role of probability is that there is no explicit and comprehensive definition of probability that could be applied universally to all branches of science." 20 This is deeply true, but I do not think it poses a problem. Let us focus on finance. In one corner, we work with the carefully estimated parameters of distributions that are defined with pinpoint accuracy (derivative pricing); in the other, due to the perfect absence of data the expected yield implicitly fulfils the role of the risk measurement number (used to discount the imagined cash flows of startup companies when applying the expected yield of companies judged to be in a similar situation). All of this takes place without it even occurring to the naive market actor that they have weighed up any possible outcomes.

From this perspective, the CAPM is nothing other than an experiment in giving a sense of the hidden relationship between logical probability and frequency prob-

\footnotetext{
19 Assuming that all other parameters are the same, of course. 20 Op. cit. 5.
} 
ability. With reversed application of the Black-Scholes equation, when calculating implied volatility we work backwards to calculate what estimated volatility would throw up the option price observed in the market; that is, what volatility do market actors (who bet their own money on their opinions) unconsciously expect in the following period. We can also use the CAPM in reverse: What implicit beta do we assume for a specific company if this or that discount rate is applied when valuing the company.

In my view, the expectation of a "comprehensive definition of probability that could be applied universally to all branches of science" is too ambitious. Probability theory is just another tool. Sometimes you need a hammer, sometimes a pair of pliers. At other times, instead of pliers you need a screwdriver. Even if there were a definition that can be used for everything, a sort of "scientific Swiss army knife", it might be too abstract and a little uninformative for practical application. ${ }^{21}$

The "invention" of derivation and integration has been one of the most influential breakthroughs in the history of science. ${ }^{22}$ But are the functions that use these specialist tools really continuous? Is the demand and supply curve really continuous, guaranteeing that the two will eventually meet at some price point? ${ }^{23}$ In finance, we often view discontinuous things as being continuous. There is certainly no such thing as continuous capitalisation, and exchange rates and interest rates are certainly quoted to a finite number of decimal places. So, when we use a discrete and when we use a continuous model it is a matter of preference and expedience. The same applies when to comes to determining when a situation can be regarded as deterministic or stochastic (and if the latter, in what sense). The most elegant example of this is the Feynman-Kac formula, where approaching the problem as a conditional expected value process can help in solving a deterministic partial differential equation; or, to stick with a far simpler example: when performing the estimation of $\pi$ a Monte Carlo simulation with the help of random numbers.

\footnotetext{
21 With square matrixes we interpret a series of concepts (determinant, inverse, own value, etc.), whereas with general matrixes (e.g. $m \times n=3 \times 125$ ) there is less that we can articulate.

22 Keep in mind that the beginnings date back to Archimedes.

23 It is guaranteed that this is not true of the vineyard-hoeing supply and demand function in the Balaton Highlands.
} 


\section{Probability, Chance, Relative Weights}

I continue to lean towards the conclusion that "there is no true interpretation of the concept of probability for the purpose of economics and finance. It is not the case that one definition or the other is the most adequate, rather that

- sometimes it is relative frequency building reliably on statistical data,

- sometimes it is an almost blind evaluation of chances $^{24}$,

- and when pricing derivative products, it is a consistent weighting criterion.

Our task is to distinguish, in clear terms, what we have in mind."25

\section{Kahnemann}

Some readers of the (BD) study may be reminded of two things in relation to this:

- fuzzy sets ${ }^{26}$,

- the book by Nobel Memorial Prize in Economic Sciences laureate Daniel Kahnemann entitled: "Thinking, Fast and Slow"27, about how our brain really works in contrast to what rational thought was previously understood to mean.

\section{What lies behind the pricing of bonds with uncertain interest rates?}

Assumed probabilities, which only have a passing statistical relationship with reality (whether we know this or not), specifically: The possible interest rates must be weighted, in the course of the calculation, so that their standard deviation matches the interest rate volatility observed in the market. Apart from this, only a starting yield curve is needed. Nothing else. The expected value of the changes (sub-steps) derives from the shape of the yield curve (because, on the

24 Which of the two branching woodland paths leads to the tourists' hut? You do not need Laplace's demon for this, just a map, because it is certain to be at the end of one, and certain not to be at the end of the other. Using the word 'probability' for this situation only wears it out.

25 SzÁz, János (2011): Valószínűség, esély, relatív súlyok. Opciók és reálopciók [Probability, Chance, Relative Weights. Options and Real Options]. Hitelintézeti Szemle 10(4), 336-348.

26 BÁrdossy, GYÖrgY - Fodor, JÁnos (2011): Matematikai módszerek alkalmazása a földtudományokban [Application of Mathematical Methods in the Earth Sciences]. Magyar Tudomány, 6. (http://www.matud.iif.hu/2011/o6/og.htm).

27 Daniel Kahnemann (2011): Thinking, Fast and Slow. New York: Farrar, Straus and Giroux: (FSG). 
trinomial interest rate tree, the tree centre is calibrated accordingly in the discrete approach). The error in the weighting of the outcome is compensated for by the discounting. Here, too, the use of identical transition probabilities only fulfils the consistency criterion. We do not have to know these; we have broad scope to choose them for ourselves depending on which products' price development we regard as the base for comparison. See the use of forward rates in bond pricing with stochastic interest rates. ${ }^{28}$

\section{Two closing remarks}

1. If one of the hidden messages of the (BD) paper is that the armour of the most advanced econometric methods and complicated probability calculation toolkit often conceals only our lack of information (to put it bluntly, our ignorance) and that quantifiable risk is just an illusion, then I have to disagree with this. But neither should we forget that, due in no small measure to today's pressure to publish, sometimes thin messages receive an ornate cloak (often interwoven with mathematics). By the same token, in the business sector a database-driven result provided by advanced software also provides good shelter from responsibility.

2. In a certain sense, COVID-19 redefines the relationship of the general public and the law with probability. Based on customary legal procedures, it makes no difference if we know almost for certain that $\mathrm{X}$ killed $\mathrm{Y}$ (if it is captured on a video recording); if we do not prove it in accordance with the rules (the recording is a little blurred, or was made illegally) then X might even get away with it. Every has learned, in statistics, about the two types of errors in hypothesis testing.

In today's extraordinary situation there is approximately a $p=112 / 10^{6}$ probability that someone is infectious; and based on the figures an infected person passes the virus on to around 2-3 people, while hundreds/thousands have been near to him or her. Therefore, the $q$ probability that the person standing in front of me will infect me is far smaller than $p$, and that too is quite small at the beginning of the epidemic. It matters not that $q$ is small; it is still possible to impose fundamental restrictions on masses of people. From one minute to the next.

It has suddenly become acceptable for a French person to be fined a thousand euros for travelling to their holiday home in the country (although the chance of them infecting others or being infected at the present moment can be expressed in the thousandths of a percent). If only 1-2 people were restricted from leaving their home on the grounds that they were fraudsters or murder-

28 For more details see SzÁz, János (2019): Kvantitatív pénzügyek [Quantitative Finances], Chapter 10.2. Budapest: Nemzetközi Bankárképző Központ, 302-303. 
ers, then even if there were an $80-90 \%$ chance of them being guilty, it would still result in a legal proceeding and outrage.

A decisive factor is that we are now talking about the future and masses of people. In Pacioli's sharing problem, everyone now somehow senses that a $7 / 8-1 / 8$ division is good, and not the 5/8-3/8 division based on past facts. Why is it that millions of people, and the various political parties, all more-or-less agree that people's movement needs to be limited?

And this on the strength of a probability event that is barely visible to the naked eye. But at the same time, even now there are still masses of doubts, on both sides, surrounding whether O.J. Simpson killed on that night. The answer perhaps lies in the fact that many others suddenly started to believe in the probability that if we do not do something, then there is a $p$ probability that half the population will fall ill within weeks, and 3-4 percent of them will die.

Three weeks ago, I was still planning to go on my already paid-for skiing holiday to South Tyrol, because South Tyrol is not Lombardy, and were it not for the imposition of a certain peace treaty it would be a part of Austria (which was then still regarded as safe).

Now, on the other hand, we think twice before even going down to the corner shop.

Meanwhile, it is not the probabilities that have changed significantly, but their interpretation.

At the same time, the new pandemic also supports Kahneman's observation of how inept the automatic halves of our brains are at properly interpreting the differences between very small probabilities. for example, what is the difference between a probability of $8 / 10^{6}$ and $388 / 10^{6}$ ? So, what is it?

These miniscule probabilities would not have swayed public opinion. But the $\boldsymbol{e x}$ pected value certainly. Because this really is a mass phenomenon, so the base for projection is massive. Five thousand deaths in Italy is a comprehensible number. And ten thousand expected in the near future is a downright alarming one.

Describing the epidemiological rules and protocols in the language of probability calculus, we could say that the restriction of movement is nothing other than a drastic reduction in the number of elements $(n)$ in the Bernoulli series, in which every personal contact leads to a $q$ probability of contracting the virus. The two-metre social distancing recommendation, meanwhile, is intended to reduce $q$ itself.

The current pandemic also sheds light on another fact that is important with regard to the probability interpretation problem under discussion: The probabilities themselves also change significantly over time. So, rather than probability 
changes we are talking about stochastic processes, with parameters that change over time. In other words, the situation is usually far too complicated to make it necessary to accurately estimate and correctly interpret any well-defined probability. The probability in question, therefore, is not a number but a function. It is not even certain that it is a deterministic function. (See, for example, the stochastic volatility models, where even the degree of uncertainty is uncertain.)

In stock markets it is commonplace for faith in a price increase to boost buying and thereby also the probability of a rise, which further stimulates buying in a spiral that leads to a bubble. A collective faith in probabilities, therefore, can feed back into the probabilities themselves.

This is what we can hopefully trust in when it comes to the present pandemic, too. So, what we think about probabilities, and the interpretation thereof, is far from irrelevant. 